\title{
Biodegradasi Plastik LDPE (Low Density Polyethlene) menggunakan Kolom Winogradsky
}

\author{
Isti'anah $^{1}$, Gading Wilda Aniriani ${ }^{2 *}$, Eko Sulistiono ${ }^{2}$ \\ ${ }^{1}$ Mahasiswa Program Studi Kesehatan Lingkungan Universitas Islam Lamongan \\ ${ }^{2}$ Dosen Program Studi Kesehatan Lingkungan Universitas Islam Lamongan \\ *Coresspondence author: gading.wildaa@gmail.com, Telp: 081298833572
}

Received: 30 Juni 2020; Accepted: 29 September 2020; Published: 29 September 2020

\begin{abstract}
Abstrak
Sampah anorganik yang banyak ditemukan salah satunya adalah plastik. Sampah plastik tersebut secara alami dapat terdegradasi di lingkungan oleh mikroorganisme seperti bakteri. Tujuan dalam penelitian ini adalah Mengetahui hasil penapisan bakteri pendegradasi plastik LDPE pada tanah Tempat Pembuangan Akhir (TPA) Tambakrigadung dan persentase massa yang terdegradasi oleh bakteri. Proses penapisan bakteri dilakukan dengan metode streak plate pada media NA, sedangakan proses biodegradasi menggunakan campuran tanah TPA dengan tambahan media MSM yang dimodifikasi. Hasil penapisan bakteri didapatkan tiga koloni. Persentase penurunan massa plastik pada uji A sebesar 7,86\%, sedangkan pada uji B sebesar 13,16\%. Hal tersebut dikarenakan komposisi pada suspensi media lebih banyak sehingga akan memberikan kesempatan pada bakteri dalam memanfaatkan komponen plastik.
\end{abstract}

Kata kunci: Penapisan, Plastik LDPE, TPA Tambakrigadung, Biodegradasi

\section{Pendahuluan}

Permasalahan sampah sudah menjadi persoalan serius terutama di kota-kota besar, tidak hanya di Indonesia saja, tetapi di seluruh dunia. Peningkatan produksi sampah mengakibatkan lahan tempat pembuangan akhir (TPA) sampah juga makin terbatas. Salah satu barang yang paling sering digunakan oleh manusia untuk pemenuhan keperluan hidupnya adalah berupa plastik [1]. Pengguna plastik semakin meningkat. Plastik memiliki banyak kelebihan dibandingkan dengan bahan organik, karena ringan, transparan, tahan air dan murah. Separuh jenis plastik yang dihasilkan oleh industri tidak dapat terurai dengan mudahnya di alam. Ada beberapa jenis plastik yang tidak bisa di lebur atau dihancurkan, sehingga plastik yang tidak dapat dilebur tersebut akan dibuang dan menumpuk menjadi gunungan sampah. 
Salah satu jenis plastik yang banyak di gunakan di kalangan masyarakat adalah LDPE. Plastik jenis ini memiliki kemampuan satu kali pemakaian seperti air minum dalam kemasan, plastik jajan, plastik obat, kantong kresek. Limbah plastik khususnya LDPE yang ada di TPA umumnya hanya ditimbun (landfill), dibakar (burn) atau di daur ulang (recycle). Proses tersebut belum menyelesaikan semua permasalahan limbah plastik. Berdasarkan hal tersebut, sangat perlu dilakukan pengendalian secara biologis dengan mencari kandidat mikroorganisme pendegradasi polimer plastik sehingga jumlah sampah plastik dapat diminimalisir. Mikroorganisme tersebut diharapkan dapat mencerna plastik dengan mengeluarkan enzim sejenis protein yang dapat mempercepat reaksi kimia. Enzim ini memutus ikatan kimia dalam plastik LDPE. Pecahan molekul-molekul tersebut cukup kecil, sehingga bakteri dapat menyerap dan menggunakan karbon dalam plastik tersebut sebagai sumber makanan. Diantara jenis-jenis mikroorganisme yang memiliki kemampuan untuk mendegradasi plastik dari jenis fungi dan bakteri [2] yaitu Bacillus megaterium, Pseudomonas sp, Azotobacter, Ralstonia eutropha, Halomonas sp, Bacillus megatserium. [3] Bacillus brevis, Acidovorax delafieldii, Paenibacillus amyloticus, Bacillus pumilus, [4] Bordetella petrii, Pseudomonas aeruginosa. Oleh karena itu pada penelitian ini bertujuan untuk mengetahui uji biodegradasi LDPE pada tanah TPA dalam mengurangi volume sampah plastik menggunakan kolom winogradsky.

\section{Metode Penelitian}

\section{A. Tempat Penelitian}

Penelitian ini dilaksanakan di Laboratorium Kesehatan Lingkungan Fakultas Ilmu Kesehatan Universitas Islam Lamongan dan TPA Tambakrigadung Lamongan

\section{B. Pengambilan Sampel Tanah}

Sampel tanah diambil dari lahan timbunan sampah yang berlokasi di TPA Tambakrigadung Lamongan, dengan pola acak sebanyak 5 titik. Selanjutnya masingmasing sampel tanah dari kelima titik tersebut diambil $1 / 4 \quad \mathrm{Kg}$ per titik sampel sehingga di dapatkan 1 1/4 Kg dari jumlah titik sampel. Kemudian tanah dari kelima titik tersebut diaduk secara merata dan diayak agar didapatkan tanah yang homogen.

\section{Persiapan Plastik Uji}

Plastik LDPE dipotong dengan ukuran $5 \times 4 \mathrm{~cm} \times 5$ lembar, kemudian disterilisasi dengan menggunakan alkohol $70 \%$ selama kurang lebih 30 menit dan dikeringanginkan dengan sinar UV pada Laminar Air Flow selama 30 menit untuk mengetahui massa kering awal plastik, potongan tersebut kemudian dikeringkan dengan dibawah sinar matahari selama 3 hari. 


\section{Isolasi Bakteri}

Mengambil 5 g sampel tanah yang sudah di preparasi dan di larutkan kedalam $10 \mathrm{~mL}$ akuades steril. Kemudian disaring di kertas saring. Suspensi bakteri dilakukan pengenceran $10^{18}$ dan $10^{20}$.

\section{E. Penapisan Bakteri}

Perbedaan morfologi bentuk koloni kemudian di lakukan penapisan dengan mengambil inokulum pada setiap koloni menggunakan jarum ose secara aseptik. Setelah itu, ditumbuhkan kembali pada media NA dengan metode streak plate.

\section{F. Uji Biodegradasi}

Proses biodegradasi ini menggunakan kolom widogradsky yaitu salah satu cara sederhana untuk mempelajari hubungan silang antara dua komponen suatu lingkungan alami di laboratorium dalam membiakkan mikroba yang menyerupai kondisi ekologis sebenarnya dengan menyediakan sumber bakteri jangka panjang untuk pengkayaan kultur [5] dengan menambahkan MSM (Mineral Salt Medium), Tanah TPA dan potongan LDPE

\section{G. Persentase Penurunan Massa Plastik LDPE}

Massa plastik ditimbang sebelum dan sesudah proses degradasi dengan menggunakan neraca analytical balance kemudian dihitung menggunakan uji paired T-Test untuk membandingan rata-rata dua variabel yang lebih efektifif atau berpengaruh.

\section{Hasil dan Pembahasan}

A. Penapisan Bakteri

Berdasarkan hasil penapisan yang di peroleh dari TPC didapatkan tiga isolat jenis bakteri pada Gambar 1 berikut ini:

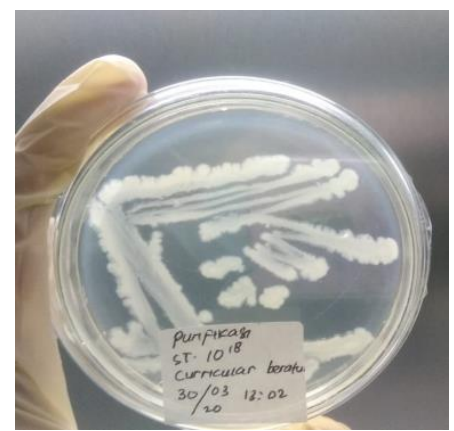

(A)

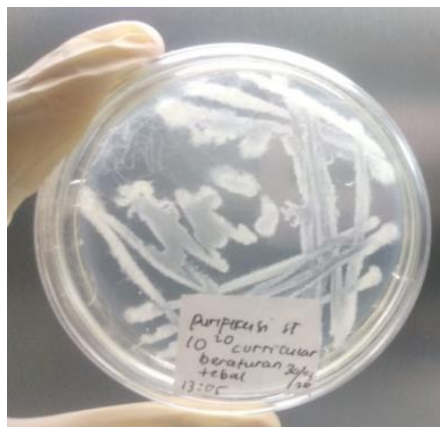

(B)

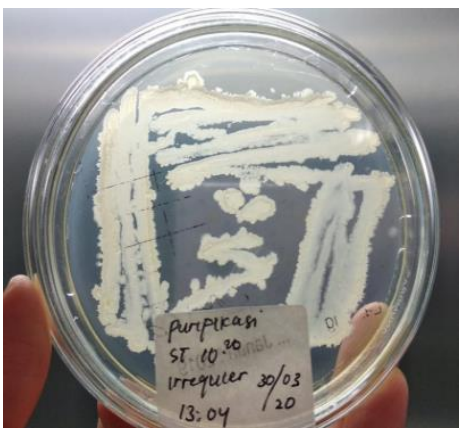

(C)

Gambar 1 Tahap Penapisan bakteri pada sampel tanah TPA.(A): koloni berbentuk bundar; (B): koloni tepian tidak beraturan; (C): Tepian berombak. 
Jumlah koloni yang diperoleh dari pengenceran $10^{18}$ ditemukan satu jenis koloni yang memiliki bentuk morfologi yang sama yaitu koloni A. Koloni tersebut berwarna krem, bentuknya bundar, tepian licin dan elevasi timbul. Hal ini serupa dengan penelitian [6] tentang seleksi bakteri pendegradasi plastik dari tanah yaitu pada isolat A1 memiliki karakter warna krem, bentuk bundar, tepian licin, dan elevasi koloni timbul.

Pada pengenceran $10^{20}$ di temukan dua morfologi yang berbeda yaitu, koloni B dan C. koloni B berwarna krem bentuk bundar, tepian tidak beraturan, dan elevasi datar. Pada jenis koloni ini memiliki kesamaan pada hasil penelitian [6] yaitu bentuk circular, tepi entire, elevasi flat, dan warna krem. Sedangkan pada koloni C yaitu koloni berwarna krem, bentuk tidak beraturan, tepian berombak, elevasi timbul. Koloni bakteri tersebut serupa juga dengan hasil penelitian [6] tentang seleksi bakteri pendegradasi plastik dari tanah dengan kode A7, yang mana bakteri tersebut memiliki potensi sebagai pendegradasi plastik

\section{B. Uji Biodegradasi}

Uji biodegradasi plastik LDPE dalam penelitian ini menggunakan kolom winogradsky. Pada kolom ini diisi sampel tanah sebagai inokulum dan Mineral Salt Medium (MSM) Modifikasi [7]. Pada Uji A pemberian sampel tanah sebanyak 40 g, sedangkan pada uji B sebanyak 80 g. Proses biodegradasi plastik LDPE dari setiap minggunya mengalami perubahan yaitu warna lapisan. mikroorganisme berkembang biak dan membentuk zona atau lapisan yang berbeda. Lapisan air yang terbentuk pada minggu pertama sampai minggu keempat berasal dari endapan media MSM. [8] MSM adalah medium mineral minim sebagai sumber karbon dalam penelitiannya. Hal tersebut serupa dengan [9] yang menyatakan bahwa mikroorganisme distimulus untuk menggunakan plastik sebagai sumber karbon.

Kolom winogradsky yang dilakukan secara aerob memiliki kelebihan dalam proses degradasi plastik oleh bakteri. [10] Pada keadaan aerob, beberapa mikroorganisme menggunakan oksigen sebagai electron acceptor terakhir. Kemampuan penggunaan oksigen ini mempengaruhi tingkat pertumbuhan bakteri pada kolom winogradsky. Pada kolom tersebut akan terbentuk zona aerob dan anaerob. 


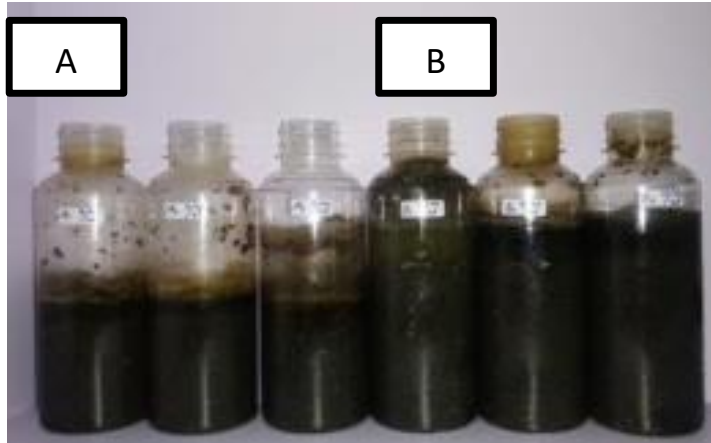

Gambar 2. Uji Biodegradasi pada Kolom Winogradsky Keterangan : A sampel tanah $40 \mathrm{~g}$, B. Sampel tanah $80 \mathrm{~g}$

\section{Persentase Penurunan Massa Plastik}

Tabel 1. Persentase Penurunan Massa Platik

\begin{tabular}{|c|c|c|c|r|}
\hline Uji & $\begin{array}{c}\text { Massa } \\
\text { Awal } \\
(\mathrm{g})\end{array}$ & $\begin{array}{c}\text { Massa } \\
\text { Akhir } \\
(\mathrm{g})\end{array}$ & $\begin{array}{c}\text { Degradasi } \\
(\mathrm{g})\end{array}$ & Persentase (\%) \\
\hline A & 0,0823 & 0,0758 & 0,0065 & 7,86 \\
\hline B & 0,0823 & 0,0715 & 0,0108 & 13,16 \\
\hline
\end{tabular}

Sumber : Data primer, 2020

Persentase kehilangan massa plastik pada uji A mengalami degradasi sebanyak 0.0065 g dengan persentase sebesar $7.86 \%$. Sedangkan uji B mengalami degradasi 0.0108 g dengan persentase sebesar $13.16 \%$. Uji B memiliki komposisi suspense tanah yang lebih banyak dibandinkan dengan uji A yakni sebesar 40 g dengan 80 g. Penurunan massa plastik tertinggi adalah uji B dengan massa awal sebanyak $0.0823 \mathrm{~g}$ dan massa akhir sebanyak $0.0715 \mathrm{~g}$.

Tabel 2. Hasil Uji Rata-Rata Sebelum dan Sesudah Proses Degradasi

\section{Paired Samples Test}

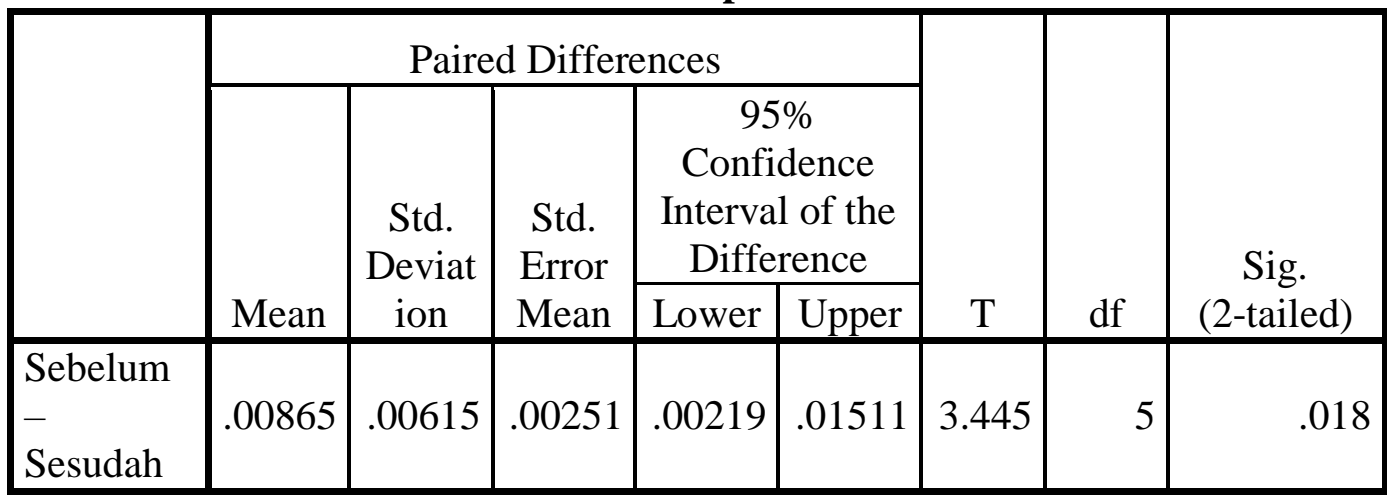


Berdasarkan hasil analisis uji $\mathrm{T}$ paired sampels, maka dapat disimpulkan bahwa $\mathrm{T}$ hitung lebih besar dari $\mathrm{T}$ tabel $(3.445>2.776)$, maka Ho di tolak H1 diterima, yang artinya terdapat perbedaan massa plastik sebelum dan sesudah proses biodegradasi.

Berdasarkan hasil penelitian Tabel 1 bakteri di duga dapat mendegradasi plastik, hal tersebut dibuktikan dengan adanya penurunan massa plastik pada saat awal perhitungan dan pada saat akhir uji proses biodegradasi. [11] Penurunan massa plastik dikarenakan bakteri menggunakan potongan plastik LDPE sebagai satu-satunya sumber karbon. Sehingga senyawa tersebut dengan mudah diangkut ke dalam sel bakteri sebagai sumber karbon dan energi. Hal ini memperkuat asumsi bahwa ada agen biodegradasi pada tanah TPA dimana pada hari 30 merupakan fase optimum isolat uji untuk melakukan proses degradasi dari total 30 hari masa inkubasi yang dilakukan. Ukuran potongan plastik LDPE yang digunakan dalam penelitian ini didasarkan pada efektifitas bakteri dalam mendegradasi plastik tersebut, jika plastik ukuran terlalu besar maka akan banyak memakan ruang pada kolom. Jika ukuran terlalu kecil maka akan menyulitkan saat proses penimbangan plastik.

Berdasarkan Tabel 2 hasil analisis uji $\mathrm{T}$ paired sampels menunjukan bahwa nilai $\mathrm{T}$ hitung lebih tinggi dari nilai $\mathrm{T}$ tabel dan Sig. (2 tailed) .018. Nilai rata-rata (mean) massa plastik sebelum proses degradasi ternyata lebih tinggi dibandingkan dengan sesudahnya. Dalam hal ini terdapat penurunan yang signifikan dengan adanya bakteri pendegradsi dalam mengurangi massa plastik LDPE. Maka proses biodegradasi ini sangat efektif dalam upaya mengurangi volume sampah anorganik khususnya plastik LDPE

\section{Kesimpulan}

Pada uji A massa plastik yang terdegradasi sebanyak 7,86\% sedangkan pada uji B 13,16\%. Hal tersebut dikarenakan komposisi pada suspensi media lebih banyak sehingga akan memberikan kesempatan pada bakteri dalam memanfaatkan komponen plastik. 
Acknowledgments: Terima kasih penulis sampaikan kepada semua pihak yang terlibat dalam penelitian ini.

Conflicts of Interest: The authors declare no conflict of interest

\section{Daftar Pustaka}

[1] Ermawati R., 2011. Konversi Limbah Plastik Sebagai Sumber Energi Alternatif Converting Of Plastic Waste As A Source Of Energy Alternative. Jurnal Riset Industri. Vol V (3). 257-263

[2] Chee, J.Y., dkk. 2010. Bacterially Produced Polyhydroxyalkanoate (PHA): Converting Renewable Resources into Bioplastics, edited by Mendez Vilas A. Applied

[3] Hayase, N, Yano H, Kudoh E, Tsutsumi C, Ushio K, Miyahara Y, Tanaka S, Nakagawa K., 2004. Isolation and characterization of poly (butylene succinate-co-butylene adipate) degrading microorganism.J Biosci Bioeng 2004; 97: 131-133 DOI: https://doi.org/10.1016/S1389-1723(04)70180-2

[4] Lee, S., Kim, M., 2010. Isolation of bacteria degrading poly (butylenesuccinate-cobutylene adipate) and their lip A gene. Int Biodeterior Biodegrad 2010; 64: 184-190. DOI: https://doi.org/10.1016/j.ibiod.2010.01.002.

[5] Anuar, K., 2014. Laporan Praktikum Mikrobiologi lingkungan kolom Winogradsky. Fakultas Matematika dan Ilmu Pengetahuan Alam. Riau Pekan baru

[6] Gultom, E. S., 2017. Seleksi Bakteri Pendegradasi Plastik dari Tanah. Jurnal Generasi Kampus. 10.(2)

[7] Danela, S. 2019. Kacang Kedelai Sebagai Media Alternatif Pertumbuhan Bakteri Pseudomonas Aeruginosa. Jurnal Analis Medika Bio Sains. 6(1).

[8] Ainiyah Dewi N. dan Shovitri M., 2014. Bakteri Tanah Sampah Pendegradasi Plastik dalam Kolom Winogradsky. Jurnal Sains dan Seni Pomits,3(2).

[9] Fadlilah, F. R. dan Maya Shovitri., 2014. Potensi Isolat Bakteri Bacillus dalam Mendegradasi Plastik dengan Metode Kolom Winogradsky. Jurnal Teknik Pomits. 3(2): $40-43$

[10] Martinko, J. M. \& Parker, J. Brock., 2000 "Biology of Microorganisms, 9th Edition”.Upper Saddle River,New York : Prentice-Hall. 


\section{Vol. 4 No. 2 Tahun 2020 Page 96-103}

Article

[11] Thakur, P.B. and C. Balomajumder., 2012. Biodegradation of O-Xylene by Azotobacter chroococcum. International Journal of Advanced Biotechnology and Research. 3: 502508. 